\title{
Effect of addition of protein concentrates from natural and yeast fermented rice bran on the rheological and technological properties of wheat bread
}

\begin{abstract}
The effect of substituting wheat flour with $0 \%, 5 \%, 10 \%$ and $15 \%$ protein concentrates from natural and yeast fermented rice bran on the rheological properties of their dough and bread properties was studied. Rheological properties of wheat dough were influenced by addition of rice bran protein concentrates. Overall acceptability score and specific loaf volume of $100 \%$ wheat bread were not significantly different from composite bread up to $10 \%$ rice bran protein substitution, and therefore, the optimised level of substitution was established. The optimised composite bread contained higher total amino acid content, radical scavenging activity and ferric reducing ability power (43.04ï $48.87 \mathrm{~g} / 100 \mathrm{~g}, 182.77 і ̈ 201.65 \mathrm{mmol}$ TEAC/100 g and 613.29ï $637.81 \mathrm{mmol} \mathrm{TE} / 100 \mathrm{~g})$ than control $(33.86 \mathrm{~g} / 100 \mathrm{~g}, 109.43 \mathrm{mmol}$ TEAC/100 g and $540.13 \mathrm{mmol} \mathrm{TE} / 100 \mathrm{~g}$ ). Springiness, cohesiveness and resilience values of wheat bread were not significantly different from composite bread. Scanning electron microscopy revealed that composite bread had surfaces with embedded granules like protein deposits with small spores.
\end{abstract}

Keyword: Bread; Fermented; Protein concentrate; Rheological properties; Rice bran; Technological properties 